\title{
Coloboma of the Iris
}

National Cancer Institute

\section{Source}

National Cancer Institute. Coloboma of the Iris. NCI Thesaurus. Code C98879.

A cong enital or acquired defect characterized by the presence of a hole in or adjacent to the iris. 